\title{
Status resistensi terhadap fosfin pada Tribolium castaneum Herbst (Coleoptera: Tenebrionidae) dari gudang penyimpanan biji kakao di Makassar Sulawesi Selatan
}

\author{
Phosphine resistance of Tribolium castaneum Herbts (Coleoptera: \\ Tenebrionidae) population collected from cocoa bean storages \\ in Makassar, South Sulawesi \\ Sri Widayanti ${ }^{1,2^{*}}$, Dadang ${ }^{2}$, Idham Sakti Harahap ${ }^{2}$ \\ ${ }^{1}$ Southeast Asian Regional Centre for Tropical Biology (SEAMEO BIOTROP) \\ Jalan Raya Tajur Km 6, Bogor 16134 \\ ${ }^{2}$ Departemen Proteksi Tanaman, Fakultas Pertanian, Institut Pertanian Bogor \\ Jalan Kamper, Kampus IPB Dramaga, Bogor 16680
}

(diterima Juli 2016, disetujui Maret 2017)

\begin{abstract}
ABSTRAK
Pengendalian hama pada biji kakao di penyimpanan umumnya dilakukan melalui fumigasi dengan fosfin. Serangga hama yang terpapar fosfin dalam jangka panjang dan pelaksanaan fumigasi yang tidak tepat dapat menyebabkan berkembangnya strain serangga yang resisten terhadap fosfin. Penelitian ini bertujuan untuk mengetahui status resistensi serangga kumbang tepung merah Tribolium castaneum Herbst (Coleoptera: Tenebrionidae) terhadap fosfin yang dikoleksi dari gudang penyimpanan biji kakao di Makassar, Sulawesi Selatan dan mengonfirmasi hasil pengujian resistensi melalui pengujian efikasi lapangan untuk mendapatkan dosis fosfin efektif terhadap serangga resisten. Studi dilakukan dengan melakukan koleksi T. castaneum di 5 gudang penyimpanan biji kakao di Makassar, selanjutnya diuji resistensi imago, pupa, dan larva T. castaneum di laboratorium menggunakan metode standar rekomendasi FAO dan menguji efikasi lapangan imago, pupa, dan larva serangga yang terdeteksi resisten terhadap fosfin. Hasil penelitian menunjukkan bahwa resistensi $T$. castaneum terhadap fosfin telah terjadi. Imago, pupa, dan larva $T$. castaneum telah resisten dengan faktor resistensi berturut-turut sebesar 1,15-8,08, 1,58-13,63, 1,53-3,25 kali. Hasil pengujian efikasi lapangan menunjukkan bahwa dosis fosfin 2 tablet $/ \mathrm{m}^{3}$ efektif mengendalikan strain resisten imago, larva, dan pupa T. castaneum.
\end{abstract}

Kata kunci: efikasi, fumigasi, serangga hama gudang, strain resisten

\begin{abstract}
Control of postharvest pest on cocoa beans during storage is generally conducted by fumigation with phosphine. Long-term exposure to phosphine and improper fumigation practices could stimulate the development of resistant strains against phosphine. The aims of this research were to know the resistance status of red flour beetle Tribolium castaneum Herbst (Coleoptera: Tenebrionidae) against phosphine from cocoa bean storages in Makassar, South Sulawesi and to conduct the field efficacy test of phosphine against insects resistant strain to confirm their resistance status. The study was conducted by collecting $T$. castaneum from five different cocoa beans storages in Makassar. Resistance status was tested in the laboratory using the standard method recommended by FAO
\end{abstract}

\footnotetext{
*Penulis korespondensi: Sri Widayanti. Southeast Asian Regional Centre for Tropical Biology (SEAMEO BIOTROP)

Jalan Raya Tajur Km 6, Bogor 16134, Tel: 0251 8323848, Faks: 0251 8326851, Email: s_widayanti@biotrop.org, wiwied2003@yahoo.co.id.
} 
and by conducting field efficacy test on adult strains resistant to phosphine. The results showed the presence of insect resistance to phosphine. Adult, pupae, and larvae of $T$. castaneum were found to be resistant to phosphine with the resistance factors of 1.15-8.08, 1.58-13.63, 1.53-3.25, respectively. The results of field efficacy tests showed that dosage 2 tablets $/ \mathrm{m}^{3}$ was effective in controlling resistant strain of adult, pupae, and larvae of T. castaneum.

Key words: efficacy, fumigation, resistant strain, stored product insect pests

\section{PENDAHULUAN}

Tribolium castaneum Herbst (Coleoptera: Tenebrionidae) merupakan hama utama produk simpanan di dunia yang secara ekonomi dapat menurunkan kualitas dan kuantitas makanan (Vojoudi et al. 2012), termasuk pada biji kakao di Indonesia. Pengendalian yang umum dilakukan untuk mengatasi serangan hama termasuk $T$. castaneum di penyimpanan biji kakao adalah fumigasi menggunakan fosfin.

Seiring dengan pembatasan penggunaan metil bromida berdasarkan Protokol Montreal maka fosfin menjadi pilihan utama untuk disinfestasi berbagai komoditas kering di seluruh dunia. Hal ini karena penggunaan fosfin relatif murah, efektif, dan bebas residu (Nayak et al. 2013). Penggunaan fosfin yang semakin luas dengan frekuensi yang semakin tinggi dan melebihi dosis anjuran dapat memicu berkembangnya strain hama yang resisten.

Fosfin bekerja melalui penghambatan proses respirasi sel. Mitokondria sebagai target peracunan fosfin sangat berpengaruh terhadap berkembangnya resistensi serangga terhadap fosfin. Penurunan sensitivitas mitokondria dalam proses respirasi sel dapat mengakibatkan terjadinya resistensi. Faktor-faktor yang dapat berkontribusi terhadap sensitivitas dan resistensi fosfin di antaranya adalah membran potensial mitokondria, laju aliran elektron melalui rantai respirasi mitokondria, dan level ATP (Zuryn et al. 2008).

Resistensi T. castaneum terhadap fosfin telah terjadi di beberapa negara di dunia, seperti Brazil (Pimentel et al. 2010), Amerika (Opit et al. 2012), Australia (Jagadeesan et al. 2012), India (Kaur et al. 2015), termasuk di Indonesia (Harahap et al. 2011). Di Indonesia resistensi terhadap fosfin pada beberapa jenis hama gudang di penyimpanan beras telah terjadi. T. castaneum dari gudang penyimpanan beras di Probolinggo, Indramayu, Semarang, dan Tegal telah resisten dengan faktor resistensi berturut-turut sebesar 5,5, 8,5, 3,3, dan 2,8 kali, sedangkan Rhyzopertha dominica (Fabricius) asal Probolinggo dan Ciamis telah resisten dengan faktor resistensi berturut-turut sebesar 5,9 dan 6,5 kali (Harahap et al. 2011).

Sementara itu, status perkembangan resistensi T. castaneum pada gudang penyimpanan lainnya, khususnya biji kakao di Indonesia belum tersedia (Harahap et al. 2013). Status perkembangan resistensi $T$. castaneum terhadap fosfin pada gudang penyimpanan biji kakao penting untuk diketahui karena kakao merupakan salah satu komoditas perkebunan yang berperan penting dalam perkembangan perekonomian nasional. Sejak tahun 2005 hingga 2011 Indonesia merupakan produsen kakao terbesar kedua di dunia dan Sulawesi Selatan merupakan sentra produksi kakao di Indonesia. Mutu biji kakao perlu dijaga dengan melakukan pengelolaan hama gudang yang tepat. Oleh karena itu, informasi mengenai status perkembangan resistensi $T$. castaneum sangat diperlukan sebagai dasar pengelolaan hama gudang yang dilakukan sehingga perlu dilakukan pemantauan. Penelitian ini bertujuan untuk menentukan status resistensi $T$. castaneum terhadap fosfin yang dikoleksi dari penyimpanan biji kakao di Makassar, Sulawesi Selatan dan mengonfirmasi hasil pengujian resistensi melalui pengujian efikasi lapangan untuk mendapatkan dosis fosfin efektif terhadap serangga resisten.

\section{BAHAN DAN METODE}

\section{Serangga uji}

Serangga uji T. castaneum dikumpulkan dari 5 gudang penyimpanan biji kakao di Makassar (PT A, PT B, PT C, PT D, dan PT E), Sulawesi Selatan. Serangga T. castaneum diidentifikasi dan dikembangbiakkan di Laboratorium Entomologi, Southeast Asian Regional Centre for Tropical Biology (SEAMEO BIOTROP), Bogor. Nilai discriminating concentration (DC) imago T. castaneum telah 
tersedia pada metode rekomendasi FAO (Busvine 1980), tetapi untuk larva dan pupa belum tersedia sehingga larva dan pupa T. castaneum asal Bogor yang telah dikembangbiakkan di Laboratorium Entomologi selama lebih dari 10 tahun digunakan sebagai serangga reference untuk penentuan nilai $\mathrm{LC}_{99,9}$ yang digunakan sebagai pengganti nilai (DC).

\section{Deteksi resistensi $T$. castaneum terhadap fosfin} Persiapan fumigasi. Pengujian ini menggunakan fumigan fosfin yang berasal dari formulasi berbentuk pelet dengan kandungan 56\% aluminium fosfida dan nama dagang Shenphos 56 PL dari PT Biotek Saranatama. Formulasi fosfin pelet diubah menjadi gas dengan menggunakan alat pengubah gas fosfin mengikuti metode standar rekomendasi FAO nomor 16 (Busvine 1980) (Gambar 1). Ruang fumigasi yang digunakan adalah stoples kaca (volume 2 liter) (merupakan modifikasi dari desikator pada metode rekomendasi FAO) yang diberi kawat kasa menggantung pada bagian tengah stoples sebagai tempat untuk meletakkan serangga uji dan diletakkan 1 batang magnet pengaduk (magnetic stirrer) pada bagian dasarnya (Gambar 2).

Serangga uji yang digunakan adalah F1 dari fase larva, pupa, dan imago T. castaneum. Umur imago serangga uji yang digunakan adalah 7 hari, umur pupa 1 hari, dan umur larva 14 hari. Sebanyak 50 individu serangga uji untuk setiap fase dari 5 lokasi, masing-masing dimasukkan
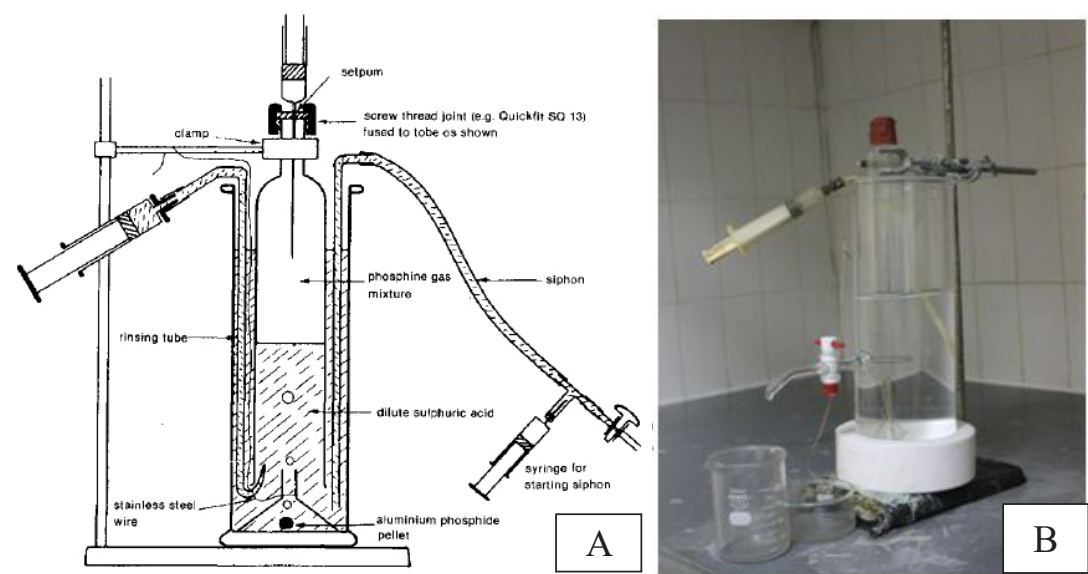

Gambar 1. Alat penghasil gas fosfin murni dari formulasi pelet aluminium fosfida, apparatus for generating phosphine. A: gambar sketsa; B: gambar asli (Busvine 1980).

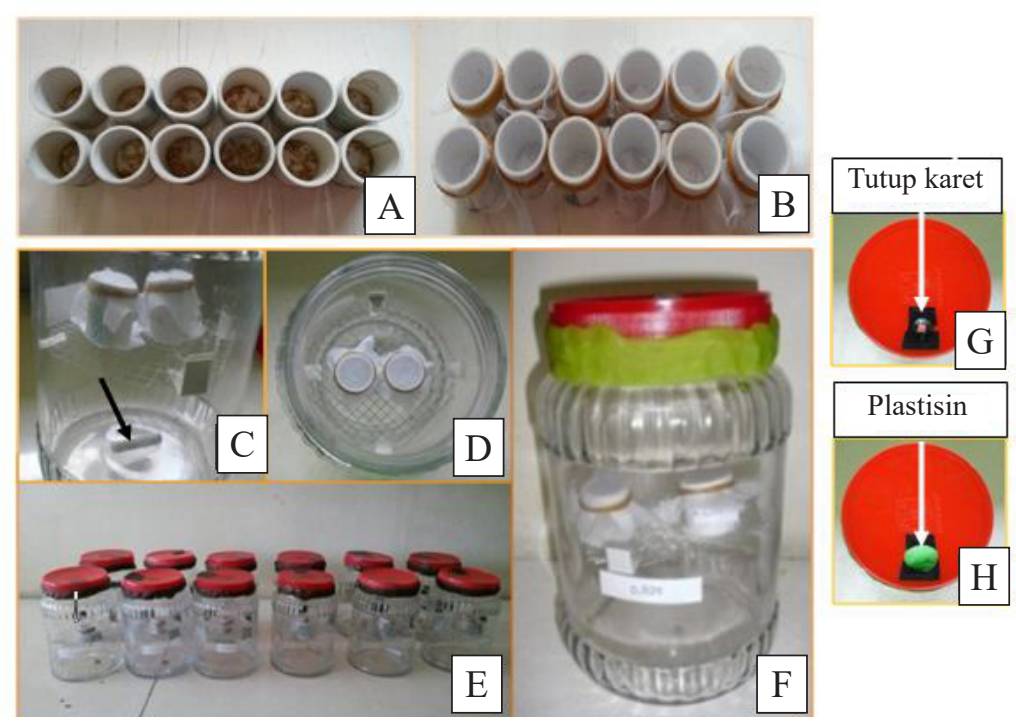

Gambar 2. Ruang fumigasi Tribolium castaneum. A, B: serangga uji dalam cincin paralon; C: magnet pengaduk gas (tanda panah); C, D, E, F: stoples kaca berisi serangga uji sebagai ruang fumigasi; G: karet penutup lubang pada tutup stoples tempat menginjeksikan gas fosfin; H: karet penutup yang telah ditutup plastisin (lilin malam). 
ke dalam cincin paralon (diameter $2,5 \mathrm{~cm}$, tinggi $2,5 \mathrm{~cm}$ ) yang diberi alas dan tutup kain kasa. Cincin paralon berisi serangga uji ini dimasukkan ke dalam ruang fumigasi yang telah diisi magnet batangan pada dasar stoples, yaitu diletakkan di atas kawat kasa pada bagian tengah stoples.

Pelaksanaan fumigasi. Pengujian terdiri atas 6 perlakuan konsentrasi fosfin dan 2 ulangan. Konsentrasi fosfin yang digunakan adalah 0,000 , $0,005,0,014,0,023,0,031$, dan 0,040 mg/l. Penentuan konsentrasi uji berdasarkan kisaran konsentrasi yang ditetapkan pada metode standar rekomendasi FAO (Busvine 1980) untuk pengujian T. castaneum, yaitu antara 0,005 dan $0,040 \mathrm{mg} / \mathrm{l}$.

Pengujian resistensi dilaksanakan dengan melakukan fumigasi serangga uji selama 20 jam. Fosfin diaplikasikan ke dalam stoples melalui sumbat karet (rubber stopper) yang terpasang pada lubang yang telah disiapkan pada tutup stoples dengan menggunakan alat suntik kedap gas (gastight syringe). Sumbat karet kemudian ditutup menggunakan lakban serta plastisin (lilin mainan) untuk mencegah kebocoran gas fosfin. Pengadukan menggunakan magnetic stirrer selama 2 menit dilakukan agar gas fosfin cepat menyebar dan homogen ke seluruh bagian stoples.

Setelah periode fumigasi selama 20 jam, serangga uji dipindahkan ke beaker glass berisi biji kakao kering sebagai pakan dan ditutup kain kasa. Pengamatan mortalitas serangga uji dilakukan setelah 14 hari. Jika terdapat indikasi resisten berdasarkan hasil analisis probit maka dilakukan pengujian lanjutan melalui perlakuan fumigasi selama 48 jam. Pengujian lanjutan ini bertujuan untuk mengonfirmasi terjadinya resistensi pada serangga uji.

\section{Pengujian efikasi lapangan serangga resisten terhadap fosfin}

Pengujian efikasi lapangan ini dirancang dengan menggunakan rancangan split split plot. Sebagai petak utama adalah dosis fosfin tablet yang terdiri atas 5 taraf $\left(0,2,3,4\right.$, dan 5 tablet $/ \mathrm{m}^{3}$ atau setara dengan konsentrasi $0,1460,2190$, 2920, dan 3650 ppm) dalam 3 blok. Lokasi asal serangga sebanyak 5 taraf, yaitu PT A, PT B, PT C, PT D, dan PT E sebagai petak bagian (Tabel 1).

Masing-masing sebanyak 20 individu imago, pupa, dan larva T. castaneum keturunan pertama (F1) dimasukkan ke dalam beaker glass (volume $150 \mathrm{ml}$ ) berisi biji kakao (20 butir). Beaker glass ditutup kain kasa (ukuran lubang 0,5 mm x 0,5 $\mathrm{mm}$ ) agar memungkinkan adanya kontak udara sehingga serangga dapat terekspos gas fosfin. Biji kakao masing-masing sebanyak $5 \mathrm{~kg}$ dikemas dalam karung plastik polipropilena. Serangga uji dalam beaker glass kemudian diletakkan di antara biji kakao dalam kantung plastik yang terbuka pada bagian atasnya. Kantung biji kakao tersebut kemudian dimasukkan ke dalam ruang fumigasi (fumigation chamber) berukuran $1 \mathrm{~m} \times 1 \mathrm{~m} \times 1 \mathrm{~m}$, dengan kerangka paralon berdiameter 0,5 inchi dan penutup plastik PVC 150 mikron. Fumigasi dilakukan di Gudang Penelitian Pascapanen SEAMEO BIOTROP selama 7 hari.

Setelah fumigasi, beaker glass berisi serangga uji dari kantung biji kakao dibawa ke laboratorium untuk dilakukan penghitungan mortalitas. Data mortalitas digunakan untuk menghitung persentase mortalitas terkoreksi menurut rumus Abbott (1925).

Penelitian dilaksanakan di Gudang Penelitian Pascapanen dan Laboratorium Entomologi, SEAMEO BIOTROP Bogor, sejak bulan Juni 2014 sampai April 2015.

Tabel 1. Lima perusahaan eksportir dan industri kakao di Makassar sebagai lokasi asal pengambilan serangga Tribolium castaneum

\begin{tabular}{ll}
\hline Lokasi & \multicolumn{1}{c}{ Komoditas yang disimpan } \\
\hline PT A & $\begin{array}{l}\text { Perusahaan eksportir berlokasi di Kawasan Industri Makassar (KIMA), menyimpan kakao lokal dan } \\
\text { kakao impor dari Ghana. }\end{array}$ \\
PT B & $\begin{array}{l}\text { Perusahaan eksportir berlokasi di Jalan Salodong Makassar, menyimpan biji kakao lokal dan biji mede. } \\
\text { PT C }\end{array}$ \\
& $\begin{array}{l}\text { Perusahaan eksportir berlokasi di Kawasan Industri Makassar (KIMA) yang menyimpan biji kakao } \\
\text { lokal. }\end{array}$ \\
PT D & $\begin{array}{l}\text { Perusahaan eksportir berlokasi di Jalan Salodong Makassar, menyimpan biji kakao lokal. } \\
\text { PT E }\end{array}$ \\
& $\begin{array}{l}\text { Perusahaan eksportir berlokasi di Jalan Ir. Sutami Makassar, menyimpan biji kakao lokal, biji mede, } \\
\text { jagung, lada, dan beras (komoditas selain kakao yang disimpan bervariasi dan situasional). }\end{array}$ \\
\hline
\end{tabular}




\section{Analisis data}

Data mortalitas terkoreksi dianalisis sidik ragam dengan tingkat perbedaan 5\%. Analisis sidik ragam dilakukan dengan menggunakan program statistik SAS 9.0.

Analisis probit dilakukan terhadap data mortalitas serangga uji menggunakan program POLO PC (Le Ora Software 1987) untuk mendapatkan nilai lethal concentration $(\mathrm{LC})_{50}$ dan $\mathrm{LC}_{99,9}$ dari masing-masing serangga uji. $\mathrm{LC}_{50}$ dan $\mathrm{LC}_{99,9}$ adalah konsentrasi yang dapat mematikan serangga uji berturut-turut sebesar $50 \%$ dan $99,9 \%$. Nilai LC $_{99,9}$ tersebut kemudian dibandingkan dengan nilai discriminating concentration (DC), yaitu konsentrasi yang mematikan semua serangga rentan yang tercantum dalam metode standar rekomendasi FAO (Busvine 1980) untuk imago T. castaneum dan nilai $\mathrm{LC}_{99,9}$ serangga reference dari Bogor untuk larva dan pupa T. castaneum untuk mengetahui faktor resistensi masing-masing serangga uji. Faktor resistensi $(\mathrm{RF}=$ resistance factor) dihitung dengan menggunakan rumus:
$\mathrm{RF}=\frac{\text { Nilai } \mathrm{LC}_{9,9} \text { serangga uji }}{\text { Nilai DC serangga uji atau } \mathrm{LC}_{99,9} \text { serangga reference }}$ Jika nilai $\mathrm{LC}_{99,9}$ serangga uji yang diperoleh lebih besar dari nilai $\mathrm{DC}$ atau nilai $\mathrm{LC}_{99,9}$ serangga reference dan nilai faktor resistensi $\mathrm{RF}$ lebih dari 1 maka serangga uji tersebut diduga resisten. Konfirmasi status resistensi lebih lanjut diperoleh dengan melakukan fumigasi selama 48 jam. Jika nilai RF lebih dari 1 maka status serangga tersebut terkonfirmasi resisten.

\section{HASIL}

\section{Deteksi resistensi $T$. castaneum terhadap fosfin}

Hasil uji resistensi melalui fumigasi 20 jam terhadap imago menunjukkan bahwa serangga dari lokasi PT A, PT B, dan PT C diduga resisten dengan faktor resistensi sebesar 6,18-15,05 kali. Hasil pengujian konfirmasi melalui fumigasi 48 jam menunjukkan bahwa serangga dari ketiga lokasi tersebut resisten dengan faktor resistensi sebesar 1,15-8,08 kali (Tabel 2). Pupa dari kelima

Tabel 2. Penduga parameter mortalitas dengan nilai $\mathrm{LC}_{50}, \mathrm{LC}_{99,9}$ dan $\mathrm{RF}$ imago Tribolium castaneum 14 hari setelah fumigasi fosfin selama 20 dan 48 jam

\begin{tabular}{|c|c|c|c|c|c|c|c|}
\hline \multirow{2}{*}{ Lokasi $^{a}$} & \multirow{2}{*}{$\mathrm{DC}^{\mathrm{b}}$} & \multirow{2}{*}{$a \pm \mathrm{GB}^{\mathrm{c}}$} & \multirow{2}{*}{$b \pm \mathrm{GB}^{\mathrm{c}}$} & $\mathrm{LC}_{50}^{\mathrm{d}}(\mathrm{mg} / \mathrm{l})$ & $\mathrm{LC}_{99,9}^{\mathrm{d}}(\mathrm{mg} / \mathrm{l})$ & \multirow{2}{*}{$\mathrm{RF}^{\mathrm{f}}$} & \multirow{2}{*}{ Status } \\
\hline & & & & \multicolumn{2}{|c|}{$\left(\right.$ SK 95\%) ${ }^{\mathrm{e}}$} & & \\
\hline \multicolumn{8}{|c|}{ Pemaparan fumigan 20 jam } \\
\hline PT A & 0,040 & $2,766 \pm 0,420$ & $1,993 \pm 0,254$ & $\begin{array}{c}0,041 \\
(-)\end{array}$ & $\begin{array}{c}0,602 \\
(-)\end{array}$ & 15.05 & Diduga resisten \\
\hline PT B & 0,040 & $5,765 \pm 0,662$ & $3,458 \pm 0,392$ & $\begin{array}{c}0,022 \\
(0,159-0,029)\end{array}$ & $\begin{array}{c}0,459 \\
(0,170-6,584)\end{array}$ & 11,48 & Diduga resisten \\
\hline PT C & 0,040 & $3,387 \pm 0,346$ & $1,745 \pm 0,194$ & $\begin{array}{c}0,011 \\
(0,008-0,407)\end{array}$ & $\begin{array}{c}0,247 \\
(0,115-1,307)\end{array}$ & 6,18 & Diduga resisten \\
\hline PT D & 0,040 & $6,812 \pm 0,535$ & $3,182 \pm 0,270$ & $\begin{array}{c}0,007 \\
(-)\end{array}$ & $\begin{array}{c}0,039 \\
(-)\end{array}$ & 0,98 & Tidak resisten \\
\hline PT E & 0,040 & $6,907 \pm 0,559$ & $3,160 \pm 0,279$ & $\begin{array}{c}0,007 \\
(0,004-0,009)\end{array}$ & $\begin{array}{c}0,036 \\
(0,023-0,085)\end{array}$ & 0,90 & Tidak resisten \\
\hline Bogor & 0,040 & $4.658 \pm 0,631$ & $1,599 \pm 0,314$ & $\begin{array}{c}0,001 \\
(0,000-0,002)\end{array}$ & $\begin{array}{c}0,035 \\
(0,023-0,081)\end{array}$ & 0,88 & Tidak resisten \\
\hline \multicolumn{8}{|c|}{ Pemaparan fumigan 48 jam } \\
\hline PT A & 0,040 & $3,308 \pm 0,364$ & $2,003 \pm 0,212$ & $\begin{array}{c}0,022 \\
(-)\end{array}$ & $\begin{array}{c}0,323 \\
(-)\end{array}$ & 8,08 & Resisten \\
\hline PT B & 0,040 & $5,642 \pm 0,503$ & $2,477 \pm 0,254$ & $\begin{array}{c}0,005 \\
(-)\end{array}$ & $\begin{array}{c}0,046 \\
(-)\end{array}$ & 1,15 & Resisten \\
\hline PT C & 0,040 & $5,537 \pm 0,414$ & $2,873 \pm 0,227$ & $\begin{array}{c}0,012 \\
(-)\end{array}$ & $\begin{array}{c}0,076 \\
(-)\end{array}$ & 1,90 & Resisten \\
\hline
\end{tabular}

${ }^{a}$ Lokasi asal serangga uji: 5 gudang penyimpanan biji kakao di Makassar dan Bogor; ${ }^{b} \mathrm{DC}$ : discriminating concentration; ${ }^{\mathrm{c}} a$ : intersep regresi probit, $b$ : kemiringan regresi probit; GB: galat baku; ${ }^{\mathrm{d}} \mathrm{LC}$ : lethal concentration; ${ }^{\mathrm{e} S K}$ : selang kepercayaan; fRF: resistance factor. 
lokasi di Makassar diduga resisten berdasarkan fumigasi 20 jam dengan faktor resistensi antara 12,1-30,47 kali dan terkonfirmasi resisten pada semua lokasi dengan faktor resistensi 1,58-13,63 kali pada pengujian 48 jam (Tabel 3). Hasil pengujian terhadap larva juga menunjukkan dugaan terjadinya resistensi pada kelima lokasi dengan faktor resistensi sebesar 4,78-14,56 kali (fumigasi $20 \mathrm{jam}$ ) dan terkonfirmasi resisten hanya pada lokasi PT A, PT B, dan PT C dengan faktor resistensi 1,53-3,25 kali (Tabel 4).

\section{Pengujian efikasi lapangan serangga resisten terhadap fosfin}

Hasil pengujian efikasi lapangan imago $T$. castaneum terhadap fosfin menunjukkan bahwa aplikasi fosfin pada semua dosis uji, yaitu 2,3,4, dan 5 tablet $/ \mathrm{m}^{3}$ memberikan respons mortalitas $100 \%$ baik imago, pupa, dan larva, sedangkan pada kontrol tidak ditemukan adanya serangga yang mati.

\section{PEMBAHASAN}

Hasil pengujian deteksi resistensi T. castaneum terhadap fosfin menunjukkan telah terjadi resistensi serangga $T$. castaneum pada biji kakao di Makassar meskipun masih pada tingkat yang rendah. Perbedaan fase perkembangan serangga memberikan respons level resistensi yang berbeda. Resistensi tertinggi terjadi pada pupa, diikuti imago dan terendah pada larva. Hal ini mengindikasikan bahwa pupa mempunyai ketahanan terhadap fosfin lebih tinggi dibandingkan dengan imago dan larva. Fase pupa dan telur lebih toleran terhadap fosfin dibandingkan dengan fase larva dan imago (Manivannan 2015; Dianxuan et al. 2016). Kaur et al. (2012) juga menunjukkan adanya perbedaan faktor resistensi (pada $\mathrm{LC}_{50}$ ) antar fase serangga $R$. dominica, yaitu berturut-turut pada telur, larva, dan pupa sebesar 400, 87, dan 181 kali. Tingginya tingkat toleransi telur dan pupa terhadap fosfin

Tabel 3. Penduga parameter mortalitas dengan nilai $\mathrm{LC}_{50}, \mathrm{LC}_{99,9}$ dan $\mathrm{RF}$ pupa Tribolium castaneum 14 hari setelah fumigasi fosfin selama 20 dan 48 jam

\begin{tabular}{|c|c|c|c|c|c|c|c|}
\hline \multirow{2}{*}{ Lokasi $^{\mathrm{a}}$} & \multirow{2}{*}{$\mathrm{DC}^{\mathrm{b}}$} & \multirow{2}{*}{$a \pm \mathrm{GB}^{\mathrm{c}}$} & \multirow{2}{*}{$b \pm \mathrm{GB}^{\mathrm{c}}$} & $\mathrm{LC}_{50}^{\mathrm{d}}(\mathrm{mg} / \mathrm{l})$ & $\mathrm{LC}_{99,9}^{\mathrm{d}}(\mathrm{mg} / \mathrm{l})$ & \multirow{2}{*}{$\mathrm{RF}^{\mathrm{f}}$} & \multirow{2}{*}{ Status } \\
\hline & & & & \multicolumn{2}{|c|}{$(\text { SK 95\%) })^{e}$} & & \\
\hline \multicolumn{8}{|c|}{ Pemaparan fumigan 20 jam } \\
\hline PT A & 0,038 & $2,253 \pm 0,326$ & $1,151 \pm 0,183$ & $\begin{array}{c}0,011 \\
(-)\end{array}$ & $\begin{array}{l}1,158 \\
(-)\end{array}$ & 30,47 & Diduga resisten \\
\hline PT B & 0,038 & $2,292 \pm 0,327$ & $1,132 \pm 0,183$ & $\begin{array}{c}0,009 \\
(-)\end{array}$ & $\begin{array}{c}1,073 \\
(-)\end{array}$ & 28,24 & Diduga resisten \\
\hline PT C & 0,038 & $2,536 \pm 0,330$ & $1,277 \pm 0,185$ & $\begin{array}{c}0,010 \\
(-)\end{array}$ & $\begin{array}{c}0,685 \\
(-)\end{array}$ & 18,00 & Diduga resisten \\
\hline PT D & 0,038 & $2,813 \pm 0,336$ & $1,496 \pm 0,190$ & $\begin{array}{c}0,013 \\
(0,007-0,019)\end{array}$ & $\begin{array}{c}0,472 \\
(0,147-18,986)\end{array}$ & 12,40 & Diduga resisten \\
\hline PT E & 0,038 & $2,800 \pm 0,335$ & $1,405 \pm 0,187$ & $\begin{array}{c}0,010 \\
(0,008-0,013)\end{array}$ & $\begin{array}{c}0,460 \\
(0,229-1,493)\end{array}$ & 12,10 & Diduga resisten \\
\hline Bogor & 0,038 & $4,894 \pm 0,598$ & $1,805 \pm 0,298$ & $\begin{array}{c}0,002 \\
(0,000-0,004)\end{array}$ & $\begin{array}{c}0,038 \\
(0,06-0,299)\end{array}$ & 1,00 & Tidak resisten \\
\hline \multicolumn{8}{|c|}{ Pemaparan fumigan 48 jam } \\
\hline PT A & 0,038 & $2,643 \pm 0,350$ & $1,108 \pm 0,192$ & $\begin{array}{c}0,004 \\
(-)\end{array}$ & $\begin{array}{c}0,518 \\
(-)\end{array}$ & 13,63 & Resisten \\
\hline PT B & 0,038 & $2,886 \pm 0,344$ & $1,349 \pm 0,189$ & $\begin{array}{c}0,007 \\
(-)\end{array}$ & $\begin{array}{c}0,385 \\
(-)\end{array}$ & 10,13 & Resisten \\
\hline PT C & 0,038 & $2,931 \pm 0,347$ & $1,346 \pm 0,191$ & $\begin{array}{c}0,007 \\
(-)\end{array}$ & $\begin{array}{c}0,355 \\
(-)\end{array}$ & 9,34 & Resisten \\
\hline PT D & 0,038 & $4,916 \pm 0,451$ & $2,118 \pm 0,232$ & $\begin{array}{c}0,005 \\
(0,002-0,007)\end{array}$ & $\begin{array}{c}0,060 \\
(0,033-0,286)\end{array}$ & 1,58 & Resisten \\
\hline PT E & 0,038 & $4,461 \pm 0,473$ & $1,759 \pm 0,243$ & $\begin{array}{c}0,003 \\
(0,000-0,005)\end{array}$ & $\begin{array}{c}0,061 \\
(0,031-0,514)\end{array}$ & 1,61 & Resisten \\
\hline
\end{tabular}

${ }^{a}$ Lokasi asal serangga uji: 5 gudang penyimpanan biji kakao di Makassar dan Bogor; ${ }^{b} \mathrm{DC}$ : discriminating concentration; ${ }^{\mathrm{c}} a$ : intersep regresi probit, $b$ : kemiringan regresi probit; GB: galat baku; ${ }^{\mathrm{d} L C}$ : lethal concentration; ${ }^{\mathrm{e}} \mathrm{SK}$ : selang kepercayaan; ${ }^{\mathrm{f}} \mathrm{RF}$ : resistance factor. 
Tabel 4. Penduga parameter mortalitas dengan nilai $\mathrm{LC}_{50}, \mathrm{LC}_{99,9}$ dan $\mathrm{RF}$ larva Tribolium castaneum 14 hari setelah fumigasi fosfin selama 20 dan 48 jam

\begin{tabular}{|c|c|c|c|c|c|c|c|}
\hline \multirow{2}{*}{ Lokasi $^{\mathrm{a}}$} & \multirow{2}{*}{$\mathrm{DC}^{\mathrm{b}}$} & \multirow{2}{*}{$a \pm \mathrm{GB}^{\mathrm{c}}$} & \multirow{2}{*}{$b \pm \mathrm{GB}^{\mathrm{c}}$} & $\mathrm{LC}_{50}^{\mathrm{d}}(\mathrm{mg} / \mathrm{l})$ & $\mathrm{LC}_{99.9}^{\mathrm{d}}(\mathrm{mg} / \mathrm{l})$ & \multirow{2}{*}{$\mathrm{RF}^{\mathrm{f}}$} & \multirow{2}{*}{ Status } \\
\hline & & & & \multicolumn{2}{|c|}{$(\mathrm{SK} 95 \%)^{\mathrm{e}}$} & & \\
\hline \multicolumn{8}{|c|}{ Pemaparan fumigan 20 jam } \\
\hline PT A & 0,036 & $2,835 \pm 0,366$ & $1,813 \pm 0,215$ & $\begin{array}{c}0,027 \\
(0,020-0,043)\end{array}$ & $\begin{array}{c}0,524 \\
(0,183-8,950)\end{array}$ & 14,56 & Diduga resisten \\
\hline PT B & 0,036 & $2,980 \pm 0,372$ & $1,938 \pm 0,219$ & $\begin{array}{c}0,029 \\
(-)\end{array}$ & $\begin{array}{l}0,460 \\
(-)\end{array}$ & 12,78 & Diduga resisten \\
\hline PT C & 0,036 & $3,419 \pm 0,406$ & $2,246 \pm 0,243$ & $\begin{array}{c}0,030 \\
(-)\end{array}$ & $\begin{array}{c}0,326 \\
(-)\end{array}$ & 9,06 & Diduga resisten \\
\hline PT D & 0,036 & $3,975 \pm 0,368$ & $2,222 \pm 0,210$ & $\begin{array}{c}0,016 \\
(0,012-0,216)\end{array}$ & $\begin{array}{c}0,181 \\
(0,089-0,957)\end{array}$ & 5,03 & Diduga resisten \\
\hline PT E & 0,036 & $4,216 \pm 0,387$ & $2,475 \pm 0,225$ & $\begin{array}{c}0,020 \\
(-)\end{array}$ & $\begin{array}{c}0,172 \\
(-)\end{array}$ & 4,78 & Diduga resisten \\
\hline Bogor & 0,040 & $5,014 \pm 0,611$ & $1,854 \pm 0,303$ & $\begin{array}{c}0,002 \\
(0,000-0,004)\end{array}$ & $\begin{array}{c}0,036 \\
(0,019-0,321)\end{array}$ & 1,00 & Tidak resisten \\
\hline \multicolumn{8}{|c|}{ Pemaparan fumigan 48 jam } \\
\hline PT A & 0,036 & $4,448 \pm 0,376$ & $2,276 \pm 0,208$ & $\begin{array}{c}0,011 \\
(-)\end{array}$ & $\begin{array}{c}0,117 \\
(-)\end{array}$ & 3,25 & Resisten \\
\hline PT B & 0,036 & $4,624 \pm 0,462$ & $1,901 \pm 0,238$ & $\begin{array}{c}0,004 \\
(0,001-0,006)\end{array}$ & $\begin{array}{c}0,062 \\
(0,311-0,592)\end{array}$ & 1,72 & Resisten \\
\hline PT C & 0,036 & $4,789 \pm 0,483$ & $1,955 \pm 0,247$ & $\begin{array}{c}0,004 \\
(0,000-0,006)\end{array}$ & $\begin{array}{c}0,055 \\
(0,027-702)\end{array}$ & 1,53 & Resisten \\
\hline PT D & 0,036 & $5,489 \pm 0,677$ & $2,055 \pm 0,329$ & $\begin{array}{c}0,002 \\
(0,001-0,003)\end{array}$ & $\begin{array}{c}0,029 \\
(0,021-0,052)\end{array}$ & 0,81 & Tidak resisten \\
\hline PT E & 0,036 & $5,809 \pm 0,560$ & $2,365 \pm 0,294$ & $\begin{array}{c}0,004 \\
(0,001-0,005)\end{array}$ & $\begin{array}{c}0034 \\
(0,021-0,092) \\
\end{array}$ & 0,94 & Tidak resisten \\
\hline
\end{tabular}

${ }^{a}$ Lokasi asal serangga uji: 5 gudang penyimpanan biji kakao di Makassar dan Bogor. ${ }^{b} \mathrm{DC}$ : discriminating doncentration; ${ }^{c} a$ : intersep regresi probit, $b$ : kemiringan regresi probit; GB: galat baku; ${ }^{\mathrm{d}} \mathrm{LC}$ : lethal concentration; ${ }^{\mathrm{e}} \mathrm{SK}$ : selang kepercayaan; RF: resistance factor.

diakibatkan oleh berkurangnya aktivitas metabolik (Kaur et al. 2012). Penurunan laju respirasi mengakibatkan penurunan dalam penyerapan fumigan yang berakibat pada tingginya tingkat toleransi serangga terhadap fumigan.

Resistensi imago $T$. castaneum telah banyak dilaporkan di dunia, dengan faktor resistensi bervariasi dari rendah hingga tinggi, yaitu sebesar 8-449 kali di Chengdu, China (Ling et al. 2007), 1-8,5 kali di Indonesia (Harahap et al. 2011), 119 kali di Oklahoma, USA (Opit et al. 2012), 2-81,2 kali di Sindh, Pakistan (Ahmad et al. 2013), sedangkan pada pengujian ini sebesar 1,9-8,1 kali. Peningkatan status resistensi pada suatu populasi serangga dapat berasal dari serangga yang bertahan selama pemaparan fumigan yang kurang efektif (Manivanna 2015).

Aktivitas perdagangan dapat menjadi media penyebaran serangga resisten. Perpindahan serangga karena perdagangan komoditas diduga sebagai faktor penyebab penyebaran serangga resisten 16
(Pimentel et al. 2010). T. castaneum pada PT A memiliki faktor resistensi tertinggi. Gudang PT A menyimpan biji kakao yang berasal dari Ghana dan Pantai Gading Afrika sehingga terdapat peluang masuknya serangga melalui telur yang tidak mati saat fumigasi dan memiliki ketahanan yang lebih tinggi. Klementz \& Reichmuth (2007) melaporkan bahwa Cryptolestes ferrugineus (Stephens) pada biji kakao impor dari Afrika Selatan ke Jerman masih dapat bertahan hidup pada paparan fosfin pada dosis $6 \mathrm{~g} / \mathrm{m}^{3}$ yang konsentrasinya di udara mencapai puncak pada 7500 ppm. Meskipun serangga dari Afrika yang dilaporkan telah resisten terhadap fosfin adalah $C$. ferrugineus, tetapi tidak menutup kemungkinan bahwa $T$. castaneum juga telah resisten dan terbawa ke Indonesia pada fase telur atau pupa yang relatif sulit terdeteksi pada saat pemeriksaan.

Level resistensi tertinggi serangga $T$. castaneum dari kelima lokasi perusahaan penyimpan biji kakao di Makassar adalah pada PT A diikuti PT 
B. Hal ini terjadi karena frekuensi fumigasi yang dilakukan untuk perawatan biji kakao di PT A dan PT B lebih sering dibandingkan dengan ketiga perusahaan lainnya (Gambar 3).

Resistensi T. castaneum yang terjadi di gudang biji kakao di Makassar masih dalam tingkat yang rendah. Hasil pengujian lapangan untuk mendapatkan dosis efektif untuk mengendalikan serangga resisten menunjukkan bahwa dosis $2,3,4$, dan 5 tablet $/ \mathrm{m}^{3}$ masih efektif untuk mengendalikan serangga resisten tersebut. Saat ini, dosis fosfin yang digunakan untuk keperluan perawatan biji kakao di gudang penyimpanan di Makassar adalah $2-5 \mathrm{~g} / \mathrm{m}^{3}$, tetapi dosis yang umum digunakan saat ini adalah $3 \mathrm{~g} / \mathrm{m}^{3}$. Dosis yang digunakan untuk keperluan perlakuan karantina dan pra-pengapalan (quarantine and pre-shipment [QPS]) adalah 2$5 \mathrm{~g} / \mathrm{m}^{3}$. Dosis ini lebih tinggi dari dosis anjuran penggunaan fosfin untuk biji-bijian di Asia, yaitu $1,5 \mathrm{~g} / \mathrm{m}^{3}$ atau $2 \mathrm{~g} /$ ton (AFHB \& ACIAR 1991). Penggunaan dosis hingga $5 \mathrm{~g} / \mathrm{m}^{3}$ merupakan upaya pemenuhan permintaan negara tujuan ekspor. Meskipun dosis aplikasi fosfin yang tinggi dapat berkontribusi terhadap perkembangan serangga resisten, tetapi dalam hal ini dosis tersebut masih dapat digunakan tanpa perlu melakukan peningkatan dosis. Jika dosis tersebut sudah tidak dapat mengendalikan serangga yang ada maka saran untuk pengendalian lebih diarahkan kepada teknik fumigasi yang benar dan memperpanjang waktu aplikasi.

Dalam kaitan dengan hasil pengujian resistensi menurut metode standar FAO, batas atas konsentrasi pengujian resistensi adalah $0,04 \mathrm{mg} / \mathrm{l}$ yang setara dengan $29 \mathrm{ppm}$ (dengan acuan $1 \mathrm{mg} / \mathrm{l}$ atau $1 \mathrm{~g} / \mathrm{m}^{3}$ setara dengan $730 \mathrm{ppm}$ (AFHB \& ACIAR 1991). Batas atas konsentrasi pengujian ini merupakan batas konsentrasi untuk mematikan serangga rentan. Konsentrasi ini sangat rendah dibandingkan dengan konsentasi atau dosis yang digunakan di lapangan, yaitu dosis 2 tablet $/ \mathrm{m}^{3}$ yang mengandung fosfin $2 \mathrm{~g} / \mathrm{m}^{3}$ yang setara dengan konsentrasi fosfin $1.460 \mathrm{ppm}$. Dengan demikian, resistensi menurut metode standar FAO yang terjadi di gudang penyimpanan biji kakao di Makassar dengan faktor resistensi maksimal sebesar 13,63 kali pada pupa T. castaneum di PT A, seharusnya dapat dikendalikan dengan konsentrasi fosfin 366 ppm sehingga dosis aplikasi yang saat ini diterapkan di gudang tersebut, yaitu dosis 2 tablet $/ \mathrm{m}^{3}$ masih dapat digunakan. Hal ini sesuai dengan hasil pengujian konfirmasi melalui uji efikasi lapangan yang menunjukkan hasil dosis 2 tablet $/ \mathrm{m}^{3}$ menimbulkan mortalitas $100 \%$ pada seluruh serangga uji. Oleh karena itu, penggunaan dosis 2 tablet $/ \mathrm{m}^{3}$ masih dapat dilanjutkan untuk mengatasi permasalahan infestasi hama $T$. castaneum. Akan tetapi, penggunaan dosis fosfin hingga 3 dan 5 tablet $/ \mathrm{m}^{3}$ yang selama ini diterapkan dalam rangka memenuhi permintaan negara tujuan ekspor dan juga digunakan untuk perawatan biji kakao di penyimpanan dalam jangka panjang akan dapat meningkatkan level resistensi serangga tersebut. Kondisi ini diperkuat dengan fakta masih belum tepatnya teknik fumigasi yang dilakukan, seperti kurang terjaganya

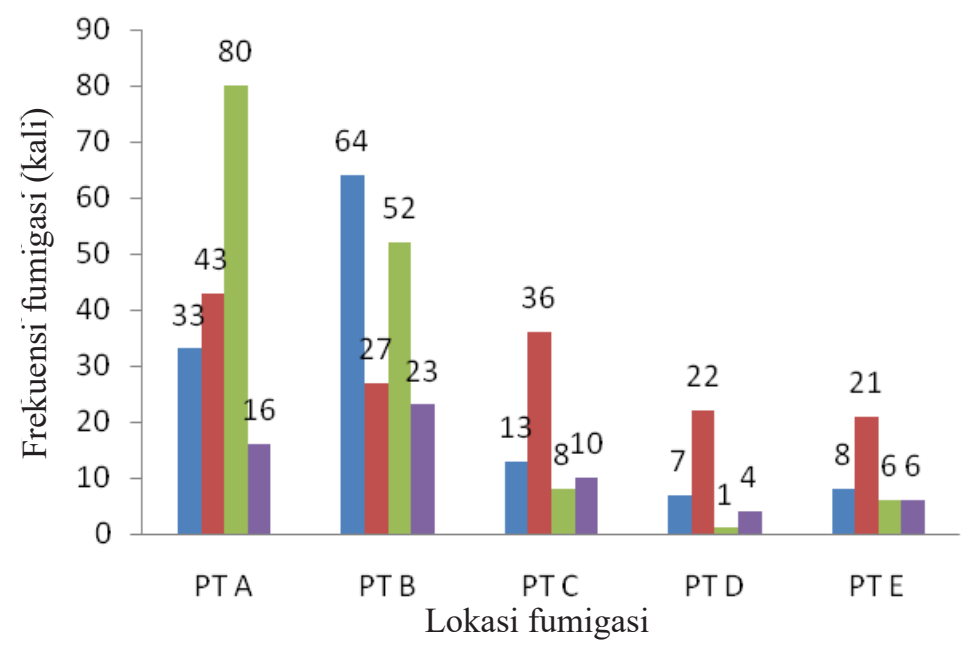

Gambar 3. Frekuensi kegiatan fumigasi di lima perusahaan penyimpan biji kakao di Makassar, pada kurun waktu tahun Mei 2012-Juni 2015. ๓: 2012; п: 2013; ๓: 2014; «: 2015. 
faktor kekedapan ruang fumigasi karena tidak sempurnanya dalam pemasangan bantalan pasir penindih plastik fumigasi.

Strategi yang dilakukan di Australia untuk mengatasi $C$. ferrugineus resisten dengan faktor resistensi 875 kali adalah dengan melakukan eradikasi untuk memusnahkan serangga resisten. Fumigasi dengan dosis $1 \mathrm{mg} / \mathrm{l}$ (720 ppm) dengan periode fumigasi 24 hari dan dosis $0,5 \mathrm{mg} / 1$ (360 $\mathrm{ppm})$ dengan periode fumigasi 30 hari berhasil mengeradikasi C. ferrugineus resisten tersebut (Nayak et al. 2010).

\section{KESIMPULAN}

Serangga hama biji kakao T. castaneum di Makassar telah menunjukkan resistensi terhadap fosfin berdasarkan metode standar FAO $(0,04 \mathrm{mg} / 1$ atau 29 ppm pada $\mathrm{LC}_{99,9}$ ) baik imago, pupa maupun larva dengan kisaran faktor resistensi berturut-turut sebesar 1,15-8,08, 1,58-13,63, 1,53-3,25 kali. Meskipun demikian, dosis fosfin 2 tablet $/ \mathrm{m}^{3}$ yang setara dengan $1460 \mathrm{ppm}$ masih dapat digunakan untuk mengendalikan serangga $T$. castaneum di lapangan.

\section{UCAPAN TERIMA KASIH}

Terima kasih disampaikan kepada Kementerian Pendidikan dan Kebudayaan atas pendanaan pada penelitian ini melalui dana DIPA SEAMEO SEAMOLEC, Pusat Studi Regional Penelitian Biologi Tropis (SEAMEO BIOTROP). Terima kasih juga disampaikan kepada pimpinan dan staf Balai Besar Karantina Pertanian Makassar yang telah membantu akses untuk pengambilan sampel biji kakao dan data fumigasi, fumigator Asosiasi Perusahaan Pengendalian Hama Indonesia cabang Makassar yang telah memberikan datadata fumigasi serta kepala gudang biji kakao di Makassar yang telah memberikan izin untuk pengambilan sampel serangga.

\section{DAFTAR PUSTAKA}

Abbott WS. 1925. A method of computing the effectiveness of an insecticide. Journal of
Economic Entomology 18:265-267. doi: https:// doi.org/10.1093/jee/18.2.265a.

[AFHB] ASEAN Food Handling Bureau, [ACIAR] Australian Centre for International Agricultural Research. 1991. Suggested Recommendations for the Fumigation of Grain in The ASEAN Region. Part 1: Principles and General Practice. Canberra: Media Works Enterprise.

Ahmad A, Ahmed M, Noorullah, Ali QM, Abbas M, Arif S. 2013. Monitoring of resistance against phosphine in stored grain insect pests in Sindh. Middle-East Journal of Scientific Research. 16:1501-1507.

Busvine JR. 1980. Recommended Methods for Measurement of Pest Resistance to Pesticides. Method for Adults of Some Major Pest Species of Stored Cereals, with Methyl Bromide and Phosphine. FAO Method No. 16. Rome: Food and Agriculture Organization of the United Nations.

Dianxuan W, Xin H, Jiting W. 2016. Resistance of phosphine to eleven strains of Tribolium castaneum and stage-specific mortality of susceptible and resistant strains. In: Navarro S, Jayas DS, Alagusundaram K, (Eds.) Proceedings of the $10^{\text {th }}$ International Conference on Controlled Atmosphere and Fumigation in Stored Products (CAF2016) (New Delhi India, 6-11 November 2016). pp. 418-424. Winnipeg: CAF Permanent Committee Secretariat.

Harahap IS, Sunjaya, Widayanti S. 2011. Laporan Penelitian. Ketahanan Serangga Hama Gudang terhadap Fosfin di Pulau Jawa: Status, Keragaan Relatif dan Pengelolaannya. Bogor: SEAMEO BIOTROP.

Harahap IS, Dewi VS, Sunjaya, Widayanti S, Guspratama S. 2013. Laporan Penelitian Permasalahan Hama Pascapanen pada Biji Kakao di Sulawesi Selatan dan Status Resistensinya terhadap Fosfin. Bogor: SEAMEO BIOTROP.

Jagadeesan R, Collins PJ, Daglish GJ, Ebert PR, Schlipalius DI. 2012. Phosphine resistance in the rust red flour beetle, Tribolium castaneum (Coleoptera: Tenebrionidae): inheritance, gene interactions and fitness costs. PLOS ONE 7: e31582. doi: https://doi.org/10.1371/journal. pone. 0031582 .

Kaur R, Schlipalius DI, Collins PJ, Swain AJ, Ebert PR. 2012. Inheritance and relative dominance, expressed as toxicity response and delayed development, of phosphine resistance in immature stages of Rhyzopertha dominica (F.) 
(Coleoptera: Bostrichidae). Journal of Stored Products Research 51:74-80. doi: https://doi. org/10.1016/j.jspr.2012.08.002.

Kaur R, Subbarayalu M, Jagadeesan R, Daglish GJ, Nayak MK, Naik HR, Ramasamy S, Subramanian C, Ebert PR, Schlipalius DI. 2015. Phosphine resistance in India is characterised by a dihydrolipoamide dehydrogenase variant that is otherwise unobserved in eukaryotes. Heredity 115:188-94. doi: https://doi.org/10.1038/ hdy.2015.24.

Klementz D, Reichmuth CH. 2007. Residues of phosphine in cocoa beans after fumigation and its effect on the rusty grain beetle Cryptolestes ferrugineus (Stephens) [abstrak]. In: Donahaye EJ, Navarro S, Bell C, Jayas D, Noyes R, Phillips TW (Eds.). Proc. Int. Conf. Controlled Atmosphere and Fumigation in Stored Products (Gold-Coast Australia, 8-13 August 2004). pp. 599. Israel: FTIC Ltd. Publishing.

Le Ora Software. 1987. Polo-PC User's Guide. Petaluma: Le Ora Software.

Ling Z, Xinfu Z, Zhitian S, Zhongwen L, Yuangfang T, Zhijun H, Xianggang W, Deqiu H, Yilin L. 2007. Phosphine fumigation of bagged and bulk paddy in Southern China using conventional and slow release application. In: Donahaye EJ, Navarro S, Bell C, Jayas D, Noyes R, Phillips TW (Eds.). Proc. Int. Conf. Controlled Atmosphere and Fumigation in Stored Products (Gold-Coast Australia, 8-13 August 2004). pp. 547-556. Israel: FTIC Ltd. Publishing.

Manivannan S. 2015. Toxicity of phosphine on the developmental stages of rust-red flour beetle, Tribolium castaneum Herbst over a range of concentrations and exposures. Journal of Food Science and Technology 52:6810-6815. doi: https://doi.org/10.1007/s13197-015-1799-y.

Nayak M, Holloway J, Pavic H, Head M, Reid R, Patrick C. 2010. Developing strategies to manage highly phosphine resistant populations of flat grain beetles in large bulk storages in Australia. In: Carvalho MO, Fields PG, Adler $\mathrm{CS}$, Arthur FH, Athanassiou CG, Campbell JF, Fleurat-Lessard F, Flinn PW, Hodges RJ, Isikber AA, Navarro S, Noyes RT, Riudavets J, Sinha KK, Thorpe GR, Timlick BH, Trematerra P, White NDG (Eds.), Proc. of the $10^{\text {th }}$ International Working Conference on Stored Product Protection (Estoril, Portugal, 27 June-2 July 2010). 425:396-401. Berlin: Julius KühnInstitut.

Nayak MK, Holloway JC, Emery RN, Pavic H, Bartleta J, Collins PJ. 2013. Strong resistance to phosphine in the rusty grain beetle, Cryptolestes ferrugineus(Stephens)(Coleoptera:Laemophloeidae): its characterisation, a rapid assay for diagnosis and its distribution in Australia. Pest Management Science 69:48-53. doi: https://doi. org/10.1002/ps.3360.

Opit GP, Philips TW, Aikins MJ, Hasan MM. 2012. Phosphine resistance in $T$. castaneum and $R$. dominica from stored wheat in Oklahoma. Journal of Economic Entomology 105:11071114. doi: https://doi.org/10.1603/EC12064.

Pimentel MAG, Faront LRDA, Silva FHD, Batista MD, Guedes RNC. 2010. Spread of phosphine resistance among Brazilian populations of three species of stored product insect. Neotropical Entomology 39:101-107. doi: https://doi. org/10.1590/S1519-566X2010000100014.

Vojoudi S, Saber M, Mahdavi V, Golshan H, Abedi Z. 2012. Efficacy of some insecticides against red flour beetle, Tribolium castaneum Herbst (Coleoptera: Tenebrionidae) adults exposed on glass, ceramic tile, plastic and paper disc surfaces. Journal of Life Sciences 6:405-410.

Zuryn S, Kuang J, Eben P. 2008. Mitochondrial modulation of phosphine toxicity and resistance in Caenorhabditis elegans. Toxicological Sciences 102:179-186. doi: https://doi. org/10.1093/toxsci/kfm278. 